Irēna Kucina

\title{
Privātuma un vārda brīvības apdraudējumi digitālajā komunikācijā un Eiropas Savienības jaunie priekšlikumi par lielo tiešsaistes platformu regulēšanu
}

Digitalizācija ir devusi sabiedrībai jaunas tehnologiskas iespējas uzlabot savu materiālo pasauli un indivīda dzìvi. Visi zina par digitālo tehnolog̣iju lietojumu medicīnā, vides piesārṇojumu samazināšanā, resursu taupīšanā un citās jomās. Arī par to, ka Saeima, valdība, iestādes, skolas, uzṇēmumi šajā pandēmijas laikā turpina darboties attālināti, nodrošinot zināmu valsts, ekonomikas un sabiedrības funkcionēšanu laikā, kad cilvēku tiešā saskarsme ir ierobežota, ir jāpateicas digitālajām tehnologíijām. Pirms 30 gadiem dzīve pandēmijas apstākḷos būtu bijusi daudz grūtāka.

Digitālā revolūcija rit pilnā sparā. Mūsu saražoto datu apjoms katru gadu dubultojas. Ilustratīi katru minūti mēs ražojam simtiem tūkstošu Google meklējumu un Facebook ziṇu. Tajos ir informācija, kas atklāj, kā mēs domājam un jūtam. Drīz lietas, kas mums ir visapkārt, iespējams, pat mūsu apgèèrbs, arī būs savienotas ar internetu.

Var sagaidīt, ka kvantu superdatori drīz pārspēs cilvēku iespējas gandrīz visās jomās. Šḳiet, ka šīs attīstības rezultātā vajadzētu veidoties viedām valstīm un viedai planētai. ${ }^{1}$

Taču līdzšinējā tehnoloǵiskā eiforija bieži nav ļāvusi saskatīt arī digitalizācijas radītos apdraudējumus demokrātijai, cilvēka brīvībai un tiesībām. Digitalizācija sola lielas iespējas, bet ir saistīta arī lieliem riskiem, it sevišķi demokrātijai un tiesiskas valsts principiem.

1 Will Democracy Survive Big Data and Artificial Intelligence? Essays on the Dark and Light Sides of the Digital Revolution. Pieejams: https://www.researchgate.net/publication/327271384_Will_Democracy_Survive_Big_Data_and_Artificial_Intelligence_Essays_on_the_Dark_and_Light_Sides_of_the_Digital_Revolution 
2020. gada 15. decembrī Eiropas Komisija nāca klajā ar diviem jauniem regulējumu priekšlikumiem (regulu formām) - Digitālo pakalpojumu tiesību akta ${ }^{2}$ un Digitālo tirgu tiesību akta ${ }^{3}$ projektiem. To primārais mērḳis ir uzlabot cilvēka darbības drošumu interneta vidē, it sevišşki kā preču un pakalpojumu patērētājam, taču pirmo reizi šie priekšlikumi satur arī punktus, kas ir svarīgi, lai mazinātu digitalizācijas apdraudējumu demokrātijai un tiesiskas valsts principiem.

Šeit autore vēēētos no tiesību viedokḷa ieskicēt divus būtiskus riskus, kas saistīti ar digitalizāciju, - Lielo datu radīto apdraudējumu cilvēka pamattiesībām uz privātumu un vārda brīvības apdraudējumu sociālajos medijos, lai pēc tam apskatītu Eiropas Komisijas 2020. gada 15. decembrī publicētos savstarpēji saistītos Digitālo pakalpojumu akta un Digitālo tirgu akta projektus un īsumā izvērtētu to dotās (un nedotās) atbildes uz šiem riskiem. Beigās autore izvirza dažas tēzes, kāda varētu būt Latvijas attieksme šo projektu apspriešanas gaitā.

\section{Lielie dati un privātuma apdraudējums}

\section{Lielie dati}

Digitalizācija nozīmē arī Lielo datu (Big Data) izveidošanos. ${ }^{4}$ Lielie Dati ir divpakāpju procesa rezultāts. Vispirms dati tiek savākti, un tas notiek arvien intensīvāk. Tad - un tā ir otrā pakāpe - tie tiek sasaistìti, savesti kopā, tādā veidā daudzkārt multiplicējot informāciju, ko šie dati satur. ${ }^{5}$

Lielos datus angḷu valodā raksturo trīs "V": to lielais apjoms (Volume), to milzīgais uzkrāšanas un pārstrādes ātrums (Velocity) un to dažādība (Variety). ${ }^{6}$

Lielie dati pirmām kārtām nozīmē lielu datu apjomu (Volume). Piemēram, sociālo mediju telpā apjoms attiecas uz datu daudzumu, kas generēts vietnēs, portālos un tiešsaistes lietojumprogrammās. Apjoms aptver pieejamos datus, kas tur atrodas un kuru atbilstība ir jānovērtē. Facebook ir 2 miljardi lietotāju, YouTube - 1 miljards lietotāju, Instagram - 700 miljoni lietotāju, Twitter 350 miljoni lietotāju. Katru dienu šie lietotāji generē miljardiem ziṇu, attēlu,

Pieejams: https://eur-lex.europa.eu/legal-content/LV/TXT/HTML/?uri=CELEX:52020PC0825\& from=LV Turpat.

4 Pääkkönen, P., Pakkala, D. (2015, December). Architecture and Classification of Technologies, Products and Services for Big Data Systems. Big Data Research, 2(4), 166-186. Pieejams: https://www. sciencedirect.com/science/article/pii/S2214579615000027

5 Turpat.

6 Turpat. 
videoklipu, tvītu utt., kas ir ārkārtīgi liels datu apjoms. Tie visi tiek sasaistīti kopā Lielajos datos. ${ }^{7}$

Uzkrāšanas un pārstrādes ātrums (Velocity) ir datu ǵenerēšanas ātrums. Paliekot pie sociālo mediju piemēra, katru dienu Google tiek veikti 3,5 miljardi meklēšanas vaicājumu, Facebook tiek augšupielādēti 900 miljoni fotoattēlu, Twitter tiek ievietoti 500 miljoni tvītu. Lielie dati palīdz to lietotājam ātri saṇemt ienākošo datu plūsmu un vienlaikus tos tikpat ātri apstrādāt. ${ }^{8}$

Dažādỉba (Variety) ir Lielo datu daudzveidība, kas attiecas uz datiem, kurus ir iespējams iegūt vai nu no cilvēkiem, vai mašīnām (datoriem, tehniskām ierīcēm u. c.). Visbiežāk tiek pievienoti strukturētie - teksti, tvīti, attēli, videoklipi u. c. Tomēr Lielajos datos iekḷauti un apstrādāti tiek arī nestrukturēti dati, piemēram, e-pasta ziņojumi, balss pasta ziņojumi, ar roku rakstīti teksti, audio ieraksti utt. Lielie dati spēj klasificēt ienākošos datus dažādās kategorijās. ${ }^{9}$ Visa šī datu daudzveidība veido Lielo datu dažādības vektoru.

Trīs "V" apraksta analizējamos datus. Analītika ir process, kā no šiem datiem iegūt vērtību kādam lietotāja nolūkam. ${ }^{10}$

\section{Datu avoti}

Lielie dati būtiski ietekmē un turpmāk vēl vairāk ietekmēs sabiedrības un indivīda dzīvi. Jautājums ir - vai un ko mēs no tiem vēlamies?

Datu avoti var tikt iedalīti divās daḷās - tehniskie avoti un cilvēki. Piemēram, ja ar modernajiem lieljaudas datoriem, drīzumā arī kvantu datoriem, tiek uztverti magnētiskie vil̦ṇi no tālām galaksijām, novērotas Covid-19 vīrusa mutācijas vai testētu materiālu stiprība - šādu tehnisko datu vākšana, uzkrāšana un izmantošana no sabiedrības un tiesību viedokḷa nav tik sensitīva kā tad, ja datu avots ir cilvēki, kuru dati nav anonimizēti. Tāpēc problemātiku, kas saistīta ar datiem no tehniskiem avotiem, kā arī ar anonimizētiem datiem par cilvēkiem, autore turpmāk neanalizēs.

Ja turpretim tiek vākti, uzkrāti, izmantoti neanonimizēti dati par individualizētu, konkrētu cilvēku, par viṇa izturēšanos, par viṇa atrašanās vietu, par komunikāciju ar citiem cilvēkiem, par viṇa ķermeni - tad jau tā ir pavisam cita

7 Unterstanding the 3 vs of Big Data - Volume, Velocity and Variety. (2017, September 8). Pieejams: https://www.whishworks.com/blog/data-analytics/understanding-the-3-vs-of-big-data-volume-velocityand-variety/

8 Turpat.

9 Turpat.

10 Volume, velocity, and variety: Understanding the three V's of big data, 2018. Pieejams: https://www. zdnet.com/article/volume-velocity-and-variety-understanding-the-three-vs-of-big-data/ 
dimensija. Tas ir ne tikai zinātnes un tehnologijas, bet arī sabiedrības, demokrātijas, politikas un tiesību jautājums.

\section{Tiesības uz privātumu}

Demokrātiskā un tiesiskā valstī cilvēkam tiek garantēts privātums.

Šīs tiesības pirmo reizi postulēja ASV Augstākās tiesas tiesnesis Luiss Brandeiss savā rakstā Right to Privacy 1890. gadā Harvard Law Review. ${ }^{11}$ Tur arī ir formulēta šo tiesību jēga un pamats - the right to be left alone. Tātad tiesỉbas "palikt vienam", t. i., lai citi l̦auj būt man pašam.

Lai arī kopš šis publikācijas ir pagājuši 130 gadi un privātuma tiesību izpratnes apjoms gan praksē, gan tiesību zinātnē tagad ir daudz plašāks un dziḷāks, to saturs, mērḳis un jēga nav mainījušies. Šìm tiesībām, kas ir cieši saistītas ar cilvēka cieņu un cilvēka subjektivitāti, ir jānodrošina iespēja būt pašam ar sevi, savā brīvtelpā, kurā viņš neatkarīgi no ārējās ietekmes var autonomi veidot savus uzskatus, savu identitāti, un lai viṇš kā subjektīva persona tiktu respektēts un kā vienlīdzīgs sabiedrības loceklis darbotos publiskajā telpā, piedalītos publiskajā diskursā. ${ }^{12}$

Latvijā šìs tiesības ir garantētas Satversmes 96. pantā. Demokrātija, kuras dziḷākā jēga ir cilvēka kā sabiedrības locekḷa pašnoteikšanās publiskajā sfērā, nevar darboties, ja šīs tiesības netiek ievērotas. Ja tās tiek nepieļaujami ierobežotas, tiek grauta demokrātiskas un tiesiskas valsts konstitūcija, valsts iekārta un sabiedriba.

\section{Tiesību uz privātumu apdraudējums}

Cilvēka digitālā novērošana jeb tracking, varētu teikt arī - izspiegošana, kas Lielajos datos uzkrāj neskaitāmi daudz pavisam dažādu datu, cilvēka profilēšana (profiling) $)^{13}$, kas dod iespēju ar algoritmu palīdzību paredzēt viņa rīcību atkarībā no konkrētā informatīvā konteksta (prediction), un šìs paredzētās rīcībās izmantošana, radot katram cilvēkam attiecīgu informatīvo kontekstu vai "burbuli", lai

11 Warren, S., Brandeis, L. The Right to Privacy. Harward Law Review, 4, 193 (Dec. 15, 1890).

12 Benn, S. Privacy, freedom, and respect for persons. In: In Ferdinand Schoeman (ed.). Philosophical Dimensions of Privacy: An Anthology. Cambridge University Press, 1984, p. 223.

13 Profilēšanas definīcija ir sniegta Vispārīgās datu aizsardzības regulas 4. panta 4. punktā: "profilēšana" ir jebkura veida automatizēta personas datu apstrāde, kas izpaužas kā personas datu izmantošana nolūkā izvērtēt konkrētus ar fizisku personu saistītus personiskus aspektus, jo īpaši analizēt vai prognozēt aspektus saistībā ar minētās fiziskās personas sniegumu darbā, ekonomisko situāciju, veselību, personīgām vēlmēm, interesēm, uzticamību, uzvedību, atrašanās vietu vai pārvietošanos. 
mērḳtiecīgi panāktu noteiktu viṇa rīcību - mikromērḳēěana (micro-targeting) -, tas ir lielo, visiem zināmo globālo tiešsaistes platformu biznesa modelis. ${ }^{14}$

Tieši šis biznesa modelis rada privātuma apdraudējumu digitālajā vidē. Šodienas realitāte ir tāda, ka cilvēks, ieejot interneta vidē, tiek izsekots un profilēts. No tā izvairīties praktiski nav iespējams ${ }^{15}$, pretējā gadījumā cilvēks internetu var lietot tikai ar ḷoti lieliem ierobežojumiem, tas savukārt praktiski nozīmē izslēgšanu no sociālās aprites. Taču šajā izsekošanā - kas ir pretrunā ar cilvēka tiesībām uz privātumu - no globālo tiešsaistes platformu un to uzņēmumu un citu struktūru viedokḷa, kas ar šo platformu starpniecibu to izmanto, ir l̦oti skaidra jēga cilvēks mērḳēešana, vēl labāk - mikromērḳēšana nolūkā panākt kādu noteiktu cilvēka rīcību.

Parasti šo manipulāciju cilvēks nejūt un neuztver. Šīs manipulācijas var būt mērḳētas, lai panāktu noteiktu cilvēka ekonomisko uzvedību, bet sevišḳi bīstami tas kḷūst, ja mērḳis ir ietekmēt cilvēka vai sabiedrības politisko nostāju un tai sekojošo politisko rīcību. Tas rada jautājumu par šāda biznesa modeļa savietojamību ar demokrātisko valsts iekārtu un tiesiskas valsts principiem. ${ }^{16}$ Tas ir liels izaicinājums datu aizsardzības sistēmām, kas faktiski nespēj šo problēmu efektīvi risināt. ${ }^{17}$

\section{Vārda brīvības apdraudējums sociālajos medijos}

Globālā digitālā vide ir radījusi jaunas iespējas vietējām, nacionālām, regionālām un globālām aktivitātēm, ieskaitot jauna veida politisko aktīvismu, kultūras apmaiṇu un cilvēktiesību īstenošanu. Globālie interneta koncerni ir radījuši

14 Zubov, S. (2019). The Age of Surveillance Capitalism. The Fight for a Human Future at the New Frontier of Power. New York, Public Affairs.

15 Reagèejot uz ES Vispārīgās datu aizsardzības regulas prasībām un Eiropas Savienības tiesas spriedumu (2019. gada 1. oktobra spriedums lietā Nr. C-673/17, Planet 49), vietnes, kuras cilvēks internetā apmeklē, tagad "lūdz" viṇa piekrišanu izvietot viṇa datorā sīkdatnes, kas izseko viṇa rīcībai. Piekrišanas definīcija ir sniegta Vispārīgās Datu aizsardzības regulas 4. panta 11. punktā: "Datu subjekta "piekrišana" ir jebkura brīvi sniegta, konkrēta, apzināta un viennozīmīga norāde uz datu subjekta vēlmēm, ar kuru viņš paziņojuma vai skaidri apstiprinošas darbỉbas veidā sniedz piekrišanu savu personas datu apstrādei."

No civiltiesību viedokḷa tomēr var tikt diskutēts jautājums, vai piekrišana bez reālas izvēles alternatīvas vispār var tikt uzskatīta par tiesiski vērā ņemamu, vismaz tad, ja ir runa par tādām vietnēm, kuras cilvēks de facto ir spiests izmantot (piemēram, valsts iestādes vai privāti monopoluzņēmumi). Jebkurā gadījumā šeit būtu jāprasa lietotāja kvalificēta piekrišana (“meaningfull consent”), ar parasto klikšḳi uz "es piekrītu” pogu nepietiek. Collection, Targeting and Profiling of Consumers Online. BEUC Discussion paper, 2020. Pieejams: https://www.beuc.eu/publications/2010-00101-01-e.pdf

16 Sal.: Bennett, C. J., Smith, O.-M. (2019). Privacy, Voter Surveillance and Democratic Engagement: Challenges for Data Protection Authorities. Pieejams: https://privacyconference2019.info/wp-content/ uploads/2019/11/Privacy-and-International-Democratic-Engagement_finalv2.pdf

17 Witzleb, N., Paterson, M. Micro-targeting in Political Campaigns: Political Promise and Democratic Risk. Pieejams: https://www.researchgate.net/publication/344839124_Micro-targeting_in_Political_ Campaigns_Political_Promise_and_Democratic_Risk 
cilvēkiem savstarpējās komunikācijas vidi, un gan liela daḷa cilvēku, gan valsts iestādes un uzņēmumi savu komunikāciju ir pārvietojuši šajā interneta vidē. Tam, ka globālie koncerni šo globālo komunikācijas vidi pārvalda pamatā saskaṇā ar savu īpašnieku noteiktajiem iekšèjiem noteikumiem, līdz šim ir pievērsta nepietiekama uzmanība.

Šì digitālā vide ir radījusi iespējas prettiesiskai tās lietošanai: naida runas vai bērnu pornogrāfijas izplatīšanai, kūdīšanai uz vardarbību utt. Reālajā vidē šādas darbïbas ir aizliegtas, un valsts iestādes par tām var sodìt ar administratīvo vai kriminālsodu, taču digitālajā vidē pieļautās vārda un informācijas aprites brīvības un privātuma robežas paliek neskaidras, izplūdušas un pakḷautas dažādām interpretācijām.

Demokrātiska un tiesiska valsts garantē informācijas un vārda brīvību. Latvijā to garantē Satversmes 100. pants. Tã ir viena no galvenajām pilsoṇa tiesībām, to ievērošana ir priekšnoteikums, lai demokrātiskā valsts iekārta varētu funkcionēt. Taču šì brīvība, tāpat kā lielākā daḷa cilvēktiesību, nav neierobežota. Tai ir robežas, kuras nosaka Satversmes 116. pants. To var ierobežot ar samērīgu likumu, lai nodrošinātu citu personu tiesības un novērstu nepārprotamus un tiešus draudus sabiedrïbai. ${ }^{18}$

Sabiedrības interesēs ir nepiel̦aut naida runu, tomēr tikpat nozīmīgi ir, lai digitālajā vidē netiktu ierobežotas tiesības uz vārda brīvību. Šāds ierobežojums piel̦aujams tikai ekstrēmā gadījumā. Kā atzinusi Eiropas Cilvēktiesību tiesa vienā no saviem pamatspriedumiem, vārda brīvība ietver arī tādas informācijas un viedokḷus, "kas apvaino, uztrauc vai šokē valsti vai kādu sabiedrības dalıu". ${ }^{19}$ Tātad jebkurš vārda brīvības ierobežojums, kas nenodara kaitējumu citu personu tiesībām, ir pilsoṇa tiesību uz vārda brīvību pārkāpums.

Lielās tiešsaistes platformas, globālie interneta koncerni ir privāti uzṇēmumi, to galvenās mītnes atrodas ASV, un tie ir pakḷauti ASV likumiem. Tie spēj kontrolēt un dzēst lietotāja augšuplādētu saturu, pamatojoties uz šo tiešsaistes platformu interpretāciju par to, vai saturs ir, piemēram, mediciniska dezinformācija, naida runa vai vardarbības veicināšana.

Taču šajās vietnēs izvietotais, lietotāju genenētais saturs vienlaikus ir arī Latvijas sabiedrības diskursa telpas, tātad demokrātiskā politiskā procesa, sastāvdaļa. ${ }^{20}$ Tās robežu noteikšana - nelikumīga satura definēšana - ir pilsoņu demokrātiski legitimētā likumdevēja uzdevums. Katrā valstī tas var būt atškirīgs. Latvijā,

\footnotetext{
18 Satversmes tiesas spriedums lietā Nr. 2003-05-09, 22. punkts.

19 Eiropas Cilvēktiesību tiesas spriedums lietā Handyside v. United Kingdom, C-5493/72, 49. punkts.

20 Sal.: Levits, E. (2016, 1. marts). Nacionālā informācijas un demokrātiskā diskursa telpa kā demokrātiskas valsts iekārtas elements. Jurista Vārds, Nr. 9.
} 
ņemot vērā vēsturisko pieredzi padomju okupācijas laikā, vārda brīvībai sabiedrības izpratnē ir īpaši svarīga nozīme.

Globālie interneta koncerni ir izveidojuši digitālo komunikācijas vidi, kas ir kḷuvusi par cilvēku galveno saziṇas vietu, bez tās cilvēks faktiski vairs nevar pilnvērtīgi piedalīties sabiedrības dzīvē, tādējādi šie koncerni ievērojamā mērā "pārvalda" mūsu sociālo dzīvi. ${ }^{21}$ Demokrātiskas valsts tiesības ietekmēt savu iedzīvotāju vārda brīvību ir skaidri noteiktas konstitūcijā, piel̦aujot to tikai ekstrēmos gadījumos, un šì ietekme ir pakḷauta neatkarīgas tiesas kontrolei. ${ }^{22}$ Turpretim globālo interneta koncernu, šo privāto uznēemumu, iespējas ietekmēt vārda brīvību ir daudz lielākas, jo tie darbojas tiesiski neregulētā vidē vai "pelēkajā zonā". Taču to atklātā un vēl jo vairāk slēptā ietekme uz cilvēku, uz demokrātiskas sabiedrības publisko diskursu un privāto komunikāciju ir ievērojama. Globālie interneta koncerni ir koncentrējuši lielu varas potenciālu - un šis varas potenciāls atrodas ārpus demokrātiskās ietekmes un kontroles.

Tāpēc pats fakts, ka globāls interneta koncerns, dzēšot, nepieļaujot vai citādi regulējot vārda brīīibu tam privāttiesiski piederošās vietnēs, kuras - apzināti ar mērḳi radīt peḷnu - ir izveidotas par galveno demokrātiskas sabiedrības diskursa vietu, ir problemātisks. ${ }^{23}$ Tas ir sabiedrïbas pamatvērtību un demokrātiskas un tiesiskas valsts iekārtas apdraudējums.

Valsts prezidents Egils Levits ir uzsvēris, ka sociālo tīklu algoritmi vai kādi mums nezināmi anonīmi cilvēki nav tiesīgi pieņemt lēmumus, kas ierobežo Satversmē garantēto vārda brīvību Latvijā. Demokrātiskā un tiesiskā valstī vārda brīvības robežas likumos nosaka demokrātiski pilnvarotais likumdevējs, un to, vai šis robežas ir pārkāptas, var lemt tikai tiesa. ${ }^{24}$

Tas ir iemesls, kādēl Eiropā diskusijas par interneta vides un it sevišķi globālo interneta koncernu - tātad lielo tiešsaistes platformu - darbības regulěšanas

${ }^{21}$ Suzor, N. P. (2019). Lawless: the secret rules that govern our digital lives and why we need new digital constitutions that protect our rights. Cambridge University Press. Pieejams: file://C:/Users/konto-2/ Downloads/Suzor\%202019\%20Lawless-2018-11-19T13_55_25.098Z.pdf

22 Skat.: Šṇepste, I. (2021, 5. janvāris). Vārda brīvības iepriekšēji ierobežojumi internetā: jēdziens un piel̦aujamība. Jurista Vārds, Nr. 1.

23 Sal.: Stjernfelt, F., Lauritzen, A. M. (2020). Your Post has been Removed. Springer Open, p. 83. Pieejams: https://link.springer.com/content/pdf/10.1007\%2F978-3-030-25968-6.pdf

24 Valsts prezidents: Vārda un mākslas brīvība nedrīkst tikt sašaurināta. Pieejams: https://www.president.lv/lv/jaunumi/zinas/valsts-prezidents-varda-un-makslas-briviba-nedrikst-tikt-sasaurinata-26622\#gsc.tab $=0$ 
nepieciešamību ${ }^{25}$ pārtop rīcībā. Ir skaidrs, ka klasiskā datu aizsardzība, arī datu aizsardzības sistēmas līdz šim augstākais sasniegums - Vispārīgā datu aizsardzības regula, ir absolūti nepietiekama, lai aizsargātu cilvēka privātumu, vārda brīvību un - līdz ar to arī demokrātiju.

\section{Digitālo pakalpojumu akta un Digitālo tirgu akta projekti}

2020. gada 15. decembrī Eiropas Komisija nāca klajā ar diviem jaunu regulu priekšlikumiem - Digitālo pakalpojumu tiesību aktu un Digitālo tirgu tiesïbu aktu.

Digitālo pakalpojumu akta projekts noteic virkni pamatnoteikumu un principu attiecībā uz to, kā tiešsaistes platformas piedalās satura publicēšanā un izplatîšanā. Digitālo pakalpojumu akta priekšlikumi satur noteikumus, kas ne tikai paredz šo platformu nosacìto atbildību par lietotāju izvietoto saturu šajās platformās, bet arī nosaka to "satura moderēšanas" (šis labāk skanīgais jēdziens tiek lietots "cenzēěanas" vietā ${ }^{26}$ ) politikas pamatnoteikumus un to izpildi. ${ }^{27}$ Priekšlikumi cita starpā paredz:

- pasākumus pret lietotāju izvietoto "nelikumīgu saturu", tostarp mehānismu, kas ḷauj citiem lietotājiem tādu saturu iezīmēt un platformām sadarboties ar īpašiem "uzticamiem signalizētājiem";

- lietotāju aizsardzības pasākumus, tostarp iespēju apstrīdēt platformu lēmumus ierobežot to saturu;

- pienākumu tiešsaistes platformām nodrošināt to algoritmu daḷēju caurskatāmību.

Būtisks jauninājums ir tas, ka īpaši tiek definēti un stingrāk nekā citi interneta uzņēmumi regulēti tieši visiem zināmie lielie globālie interneta koncerni, kuri ir galvenie cilvēku izsekošanas, profilēšanas, rīcības paredzēšanas un

Dobber, T., Ó Fathaigh, R., Zuiderveen Borgesius, F. J. (2019, 31. decembris). The regulation of online political micro-targeting in Europe. Internet Policy Review. Vol. 8, Issue 4. Pieejams: https://policyreview.info/articles/analysis/regulation-online-political-micro-targeting-europe

Priekšlikums Eiropas Parlamenta un Padomes Regulai par digitālo pakalpojumu vienoto tirgu (Digitālo pakalpojumu tiesību akts), ar ko groza Direktivu 2000/31/EK, 15.12.2020. Pieejams: https://eur-lex. europa.eu/legal-content/LV/TXT/HTML/?uri=CELEX:52020PC0825\&from=en

Priekšlikums Eiropas Parlamenta un Padomes Regulai par sāncensīgiem un godīgiem tirgiem digitālajā nozarē (Digitālo tirgu tiesību akts), 15.12.2020. Pieejams: https://eur-lex.europa.eu/legal-content/ LV/TXT/HTML/?uri=CELEX:52020PC0842\&from=en

Dobber, T., Ó Fathaigh, R., Zuiderveen Borgesius, F. J. (2019, 31. decembris). The regulation of online political micro-targeting in Europe. Internet Policy Review. Vol. 8, Issue 4. Pieejams: https://policyreview.info/articles/analysis/regulation-online-political-micro-targeting-europe

26 Skat. arī: Stjernefelt, F., Lauritzen, A. M. (2020). Facebook and Google as Offices of Censorship. Pieejams: file:///C:/Users/konto-2/Downloads/Facebook_and_Google_as_Offices_of_Censorship.pdf

27 Barata, J. (2021, 2. marts). The Digital Services Act and the Reproduction of Old Confusions. Pieejams: https://verfassungsblog.de/dsa-confusions/ 
ietekmēšanas mehānisma darbinātāji. Tie tiek apzīmēti par "ḷoti lielām tiešsaistes platformām" un definēti kā "tiešsaistes platformas, kuru pakalpojumi sasniedz vismaz 10\% no Eiropas Savienības iedzīvotāju skaita” (25. pants).

Digitālo tirgu akts cita starpā paredz definēt kritēriju kopumu, pēc kuriem liela tiešsaistes platforma kvalificējama par piekḷuves kontrolieri. Tie ir:

- spēcīga ekonomiskā pozīcija, būtiska ietekme iekšējā tirgū, un tas darbojas vairākās ES valstīs;

- spēcīga starpniecíbas pozīcija, kas nozīmē, ka tas saista lielu lietotāju skaitu;

- ir (vai drīzumā būs) nostiprināta un ilgtspèjīga pozīcija tirgū, kas nozīmē, ka tas laika gaitā ir stabils.

Šādam par "piekḷuves kontrolieri” definētam uzṇēmumam - faktiski runa ir galvenokārt par globālajiem interneta koncerniem - ir jāpilda noteikti pienākumi, lai nodrošinātu taisnīgāku komercvidi, it sevišķi maziem un vidējiem uzṇēmumiem, jaunuzṇēmumiem. Piemēram, interneta meklētājplatforma (piemēram, Google) vairs nedrīkstēs savus vai tai piederošu uzṇēmumu vai sadarbības partneru produktus meklēšanas rezultātu sarakstā "izbīdīt" priekšgalā.

\section{Projektu problemātiskie punkti}

Par šiem jaunajiem Eiropas Komisijas regulējumu priekšlikumiem Eiropā jau ir sākusies diskusija (Latviju pagaidām tā vēl nav sasniegusi), un netrūkst arī kritikas. Sistēmiski būtiskākie kritikas punkti ir divi.

Pirmkārt, Digitālo pakalpojumu akts lielu vērību pievērš "nelikumīga satura" izskaušanai, uzliekot interneta uzṇēmumiem pienākumu to vispirms darìt pašiem. Tas nozīmē, ka viṇiem ir jāatrod lietotāju tur izvietotais "nelikumīgs saturs". Uzñēmums to var darīt ar citu lietotāju ziņojumu, īpašu "uzticamu signalizētāju" palīdzību, kā arī pēc savas iniciatīvas. Tas automātiski rada jautājumus vai šiem uzņēmumiem tagad ir delegétas tiesības cenzēt tur izvietoto saturu? Kà tas ir savietojams ar vārda brīvības nodrošināšanu, kuras robežas demokrātiskā un tiesiskā valstī nosaka demokrātiski leǵitīms likumdevējs? Jāṇem vērā, ka praktiski jebkura par nelikumīgu uzskatīta satura dzēšana var radīt domstarpỉbas par to, vai tas patiešām ir bijis nelikumīgs. Vai tiešām šos jautājumus no tiesỉbu viedokḷa drīkst izškirt ar algoritmu palīdzību? ${ }^{28}$ Kā praksē varētu darboties apstrīdēšanas mehānisms, ṇemot vērā šādu strīdu iespējamo lielo skaitu? Vai patlaban

28 Par algoritmu lietošanas robežām lēmumu pieņemšanā tiesiskā procedūrā sal.: Kucina, I. (2021). Algorithms in Courts and Predictive Justice. In: Julia Iliopoulos-Strangas, Egils Levits, Michael Potacs, Jacques Ziller (Hrsg.): Die Herausforderungen der digitalen Kommunikation für den Staat und seine demokratische Staatsform. The Challenges of Digital Communication for the State and its Democratic State Form. Nomos, Baden-Baden; Stämpfli, Bern; Sakkoulas, Athens. 
acīmredzot lietotais "aizliegto vārdu" saraksts, kas publiski nav pieejams un kuru lieto šo lielo platformu algoritmi, ir piel̦aujams no tiesiskas valsts viedokḷa, ņemot vērā, ka tas var radīt brīvai, demokrātiskai sabiedrībai nepien,emamu pašcenzūras efektu? ${ }^{29}$

Otrkārt, Eiropas Komisijai ir pietrūcis drosmes (visticamāk, ir darbojušies attiecīgie lobiji) nopietni ierobežot vai, vēl labāk, aizliegt izsekošanu, profilēšanu un mikromērķēšanu. ${ }^{30} \mathrm{Ka}$ jau iepriekš minēts, tieši izsekošana un profilěšana mikromērķēšanas nolūkos kā visas cilvēka digitālās izsekošanas infrastruktūras galvenais mērķis ir tas, kas ietekmē cilvēka privātumu un padara viṇu mērķtiecīgi manipulējamu. Ja tas notiek tiešās vai netiešās politiskās interesēs, tad ar to tiek skarts pats demokrātijas kodols.

Tomēr pozitīvi ir tas, ka Digitālo tirgu akta 29. pants pirmo reizi, gan visai uzmanīgi, ir pievērsis uzmanību šai izsekošanas, profilēěanas un mikromērķēšanas infrastruktūrai. Pants nosaka, ka lielajām tiešsaistes platformām savos noteikumos jānosaka savās ieteikumu sistēmās izmantotie parametri, kā arī pakalpojuma saṇēmēju iespējas ietekmēt šādus galvenos parametrus, kurus tās ir darījušas pieejamus, to starpā vismaz vienu iespēju, kas nav balstīta uz profilēšanu. Tas nodrošinātu lietotājam zināmu transparenci un iespēju ietekmēt to, kā lielās tiešsaistes platformas ietekmē vinuu. Un tas jau ir progress ceḷā uz šìs problēmas patiesu risināšanu.

Problemātisks ir arī Digitālo pakalpojumu akta tvērums. Saskaṇā ar 5. un 14. pantu tas ietver jebkāda veida platformu pakalpojumus - ne tikai sociālos medijus, bet arī e-pastus, mākoņpakalpojumus u. c. Vai tas nozīmēs, ka cenzūra tiks attiecināta arī uz privātajiem e-pastiem un informāciju, ko lietotājs glabā mākonī? ${ }^{31}$

Tāpat neviens no abiem jaunajiem projektiem nepiemin lielo tiešsaistes platformu atbildību par lietotāju uzglabāto datu noplūdi. 2021. gada aprīḷa sākumā 533 miljonu Facebook lietotāju dati (personīga informācija, telefona numuri) tika izplatīti internetā. ${ }^{32}$ Kāda ir Facebook atbildība? Vai tam jāpaziņo šis fakts attiecīgajiem lietotājiem? Vai lietotāji var no Facebook prasīt morālu vai materiālu kompensāciju?

29 Sal.: Benesch, S. (2020). But Facebook's Not a Country. How to Interpret Human Rights Law for Social Media Companies. Yale Journal on Regulation Online Bulletin. Pieejams: https://digitalcommons.law. yale.edu/jregonline/3/

30 At a Glance: Does the EU Digital Services Act protect freedom of expression? Pieejams: https://www. article19.org/resources/does-the-digital-services-act-protect-freedom-of-expression/

31 Turpat.

32533 million Facebook users' phone numbers and personal data have been leaked online. (2021, 3. aprīlis). Business Insider. Pieejams: https://www.businessinsider.com/stolen-data-of-533-million-facebookusers-leaked-online-2021-4 
Digitālo pakalpojumu akta un Digitālo tirgu akta projektos, bez šaubām, ir daudz interesantu un novatorisku noteikumu. Daudzos gadijumos tie ir lietotāju tiesību nostiprināšana attiecībā uz tiešsaistes uzṇēmumiem. Taču apzinoties, cik svarīgi šajos abos projektos ietvertie regulējumi būs Eiropas digitālās vides veidošanai un līdz ar to cilvēku tiesībām un iespējām izmantot šo vidi, jārēķinās, ka šie projekti tagad tiks uzmanīgi un ilgstoši apspriesti dažādos šo aktu galīgās redakcijas posmos. Šeit sadursies globālo interneta koncernu un citu tiešsaistes uzṇēmumu intereses, no vienas puses, un pilsoṇu intereses, no otras puses. Un pilsoņu interesēs ir aizstāvēt savu privātumu un vārda brīvību tādās robežās, kā to nosaka valsts likumi, nevis šo uzņēmumu intereses un priekšstati par to, ko drīkst un ko nedrīkst.

\section{Kas svarīgi Latvijai?}

Latvija, tāpat kā citas Eiropas Savienības valstis, gatavojas vērienīgai digitalizācijai. Eiropas Savienība savu dalībvalstu ekonomikas, darba pasaules, komunikācijas un citu jomu pārejā uz digitālo tehnologiju ieguldīs lielus līdzekḷus.

Kas šajā kontekstā ir svarīgi Latvijai?

Pirmkārt, jāatceras, ka digitalizācijai ir ne vien tehniska, bet arī sociāla un ar to saistīta tiesiska dimensija. Tiesību uzdevums digitalizācijā ir veicināt sabiedrībā pozitīvos efektus un aizsargāt tos no negatīvajiem.

Otrkārt, ieguldot resursus digitalizācijā, jāṇem vērā, ka ir sākusies un turpmāk arvien pastiprināsies tendence tiesiski regulēt digitālo vidi tā, lai tā nesaēstu indivīda privātumu un līdz ar to viņa patstāvīgo, uz autonomas izvēles balstīto spriestspēju. Līdzšinējie biznesa modeḷi, kas balstīti uz cilvēku izsekošanu un viņu rīcības ietekmēšanu ar mikromērķēšanas palīdzību, kurus jau tagad abi šeit apskatītie projekti mēginājuši pagaidām vēl ḷoti saudzīgi ierobežot, pārredzamā nākotnē ar lielu varbūtību nebūs ilgtspējīgi.

Treškārt, Latvijai ir iespēja nevis vienkārši gaidīt, kā viss attīstīsies, kas notiks, bet gan aktīvi piedalīties šajā diskusijā, tostarp pavisam konkrēti - formulēt un aktīvi pārstāvēt savu pozīciju par minētajiem Eiropas Komisijas projektiem. Autores ieskatā Latvijas pozīcijai jābūt tādai, kas aizstāv cilvēku, viṇa pamattiesības un brīvību. Savukārt interneta uzṇēmumiem jāatrod un Eiropas Savienības regulējumiem mērķtiecīgi jāatbalsta tādi biznesa modeḷi, kas to respektē.

Ceturtkārt, Latvijai ir iespēja arī inovatīvi atrast savus nacionālos tiesiskos risinājumus, kas precīzāk nošķir digitalizācijas pozitīvos efektus no negatīvajiem. Tiesiskā vide, juridiskā infrastruktūra ekonomikai ir tikpat svarīga kā kapitāls, darbaspēks un citi ekonomiskie faktori. Latvija var mērkstiecīgi veidot šādu 
ilgtspējīgu tiesisku vidi un tādā veidā veicināt digitalizācijas procesu un tā pozitīvos efektus, kas būtu arī papildu stimuls ekonomikai.

Piektkārt, juridiskie mehānismi, kas mums pastāv pilsonisko un politisko tiesību aizsardzībai, globālo interneta koncernu gadījumā nedod labu rezultātu. Eiropai - un Latvijai - ir iespēja attīstīt inovatīvu tiesisku pieeju attiecībā uz šo platformu atbildību un to darbības regulēšanu cilvēku interesēs, nevis vienkārši ḷaut tām patverties savā problemātiskajā biznesa modelī un visu tiesisko regulējumu veidot ap to.

Šì arī ir iespēja noteikt konstitucionālos principus, kuriem kopīgi vajadzētu būt par Eiropas kopīgās sociālās telpas pamatu digitālajā laikmetā. Diskusija par "digitālo konstitucionālismu" (digital constitutionalism) ${ }^{33}$ pēdējā laikā kḷūst arvien nozīmīgāka. Tiesiskuma vērtības, labas pārvaldības vērtības ir pamats, kā konstitucionāli konceptualizēt interneta uzṇēmumu regulējumu un pārvaldību, pakḷaut to darbību un ar to saistītos riskus demokrātiski leǵitīmam regulējumam.

33 De Gregorio, G. (2020). The Rise of Digital Constitutionalism in the European Union. International Journal of Constitutional Law. Pieejams: https://ssrn.com/abstract=3506692; Celeste, E. (2018). Digital Constitutionalism: Mapping the Constitutional Response to Digital Technology's Challenges. HIIG Discussion Paper Series No. 2018-02. Pieejams: https://ssrn.com/abstract=3219905 or http://dx.doi. org/10.2139/ssrn.3219905 